\title{
Insights from the Farm Forestry Tree Seedling Nursery Sector in Western Java, Indonesia
}

\author{
Agustin Mercado $\mathrm{Jr}^{1}$, Paul Dargusch ${ }^{2}$ and Nestor Gregorio ${ }^{3}$ \\ ${ }^{1}$ World Agroforestry Centre (ICRAF-Mindanao), MOSCAT Campus, Claveria, \\ Misamis Oriental, the Philippines \\ ${ }^{2}$ School of Integrative Systems, The University of Queensland, St Lucia, 4079, \\ Australia \\ ${ }^{3}$ College of Forestry and Natural Resources, Leyte State University, Baybay, \\ Leyte, the Philippines
}

\begin{abstract}
This paper reports observations of a study tour by the authors of the farm forestry tree seedling nursery sector in Western Java, Indonesia. Industry stakeholders were found to recognise and value high quality germplasm and seedling quality for commercial farm forestry success. These quality preferences of stakeholders are supported by the use of a simple tree seedling certification scheme through which certified seedlings receive a premium selling price. Other initiatives, including government extension efforts, tree seed centres and vegetative propagation, provide complementary support for the preference and promotion of high seedling quality in the Western Java farm forestry industry.
\end{abstract}

Keywords: clonal forestry, seedling quality certification, seedling value chain, community-based forest management

\section{INTRODUCTION}

The authors undertook a study tour of the seedling production sites in Western Java in Indonesia during December 2007. The purpose of the tour was to identify features of the Indonesian tree seedling production and distribution system that could benefit the further development of the equivalent sector in Leyte and Mindanao in the Philippines. The tour was undertaken as part of a broader research project entitled ASEM/2006/091 Enhancing Tree Seedling Supply via Economic and Policy Changes in the Philippines Nursery Sector funded by the Australian Centre for International Agricultural Research (ACIAR). Table 1 presents a summary of the organisations, offices and nurseries visited and their locations. 
Table 1. Summary of nurseries, organizations and offices visited during the tour

\begin{tabular}{|c|c|}
\hline Date & Activity \\
\hline 10 Dec 07 & $\begin{array}{l}\text { Meeting with key officials of Forestry Research and Development } \\
\text { Agency in Bogor } \\
\text { Visited the Balai Penelitian Teknologi Perbenihan (BPTP) nursery } \\
\text { at Nagrak } \\
\text { Visited a community nursery at Cipaku }\end{array}$ \\
\hline 11 Dec 07 & $\begin{array}{l}\text { Visited the Korean Overseas International Cooperation Agency } \\
\text { (KOICA) project in Rumpin and tree plantation plots at Jasinga }\end{array}$ \\
\hline 12 Dec 07 & $\begin{array}{l}\text { Visited the Biotrop Laboratory at Bogor and then the nursery of PT } \\
\text { Kuntum } \\
\text { Visited a clonal propagation facility of Pondok Pesantren }\end{array}$ \\
\hline 13 Dec 07 & $\begin{array}{l}\text { Meeting with Balai Perbenihan Tanaman Hutan (BPTH) in } \\
\text { Bandung } \\
\text { Visited a community nursery at Sumedang }\end{array}$ \\
\hline
\end{tabular}

\section{PARADIGM SHIFT TOWARDS COMMUNITY-BASED FOREST MANAGEMENT}

Forest management in Indonesia has shifted gradually from state-based forest to community-based management. This has happened mainly during the reformation period with the implementation of decentralization in 1998. After the Suharto regime in 1998, Indonesian forest policy has been reformed to reflect the movement of democratization, IMF recommendations, and as a response to forest degradation and unabated forest fires. Social forestry programs on forestland promoted by the Indonesian government include programs involving production forests controlled by companies or concessionaires as well as the people living on forestland. Agroforestry or intercropping trees including teak with agricultural crops (the Tumpang Sari system) has been practiced for more than 100 years. This is a cropping system similar to the taungya system in Burma, the Philippines and Nigeria) (Roshetko et al. 2008).

Forest companies or concessionaires were set the task of developing a forest village social development program (Pembinaan Masyarakat Desa Hutan) in which they were required to construct roads, elementary schools, clinics, churches and mosques, and to help the residents introduce agroforestry systems. The Pembinaan Masyarakat Desa Hutan (PMDH) program was obliged to forest concessionaires through the Minister of Forestry Decree No. 691/Kpts-II/1991 and has been revised twice through the Minister of Forestry Decree No. 69/Kpts-II/1995 and No. 523/KptsII/1997. The object of the program was to improve the livelihood of local people, in particular those who are living around adjacent forest areas. The program should be initiated by a diagnostic study participated in by the targeted community to identify community needs. Based on this study, the company should include the PMDH program in their annual work plan on forest management. The PMDH program could cover community capacity building on farm based activities, strengthening economic 
activities, improving village infrastructures and empowering communities in their efforts to sustain forest resources. In practice, forest concessionaires were only concerned with the approval of their annual work plan to keep their business running. In the majority of cases forest concessionaires implemented the PMDH program through building some village infrastructures, and not really addressing the necessity of improving local capacity as required by the original concept in the PMDH program

The community-based forestry program was devised to encourage community forestry to be practiced by the people, particularly those people or groups living within and near forests areas. These communities obtained a forest concession certificate (Hak Pengusahaan Hutan Kemasyarakatan) valid for a period of 35 years, under which their activities include the establishment of new plantations or management of the existed forest resources within the production forests (hutan produksi), protection forests (hutan lindung), or conservation areas (kawasan pelestarian alam). Production of wood and non-wood forest products including planting, tending, protecting, harvesting and marketing are regarded as community forestry activities which receive government subsidies. Apart from programs intended for forest occupants, the government also supports a social forestry program on private land which encourages people to plant trees. This endeavour is subsidized by the reforestation fund. The government also recognizes customary forest management as an integral part of community forest management in which indigenous people are encouraged to form an organization to develop customary regulations to manage the forests.

The main driving force for the sharp increase in tree seedling demand during the last ten years was not the community forestry itself, but the government's massive program on forest and land rehabilitation. In 2003 the GoI launched the national movement of forest and land rehabilitation (or Gerakan Rehabilitasi Hutan dan Lahan/GNRHL and later on GERHAN). This program was implemented by a massive reforestation and regreening activities in both state forest and on degraded private or community lands. A huge auction of seedlings by the government has triggered the establishment of new seedling companies, including smallholder-managed nurseries. This paradigm shift of inclusiveness of the communities living in and around the forests has created an increased demand for high quality seeds and seedlings across Indonesia to address reforestation and land rehabilitation. This also encourages more players into the seed and seedlings business thus sustaining the supply and demand for high quality seed and seedlings. 


\section{THE SEEDLING PRODUCTION INDUSTRY AND INDONESIAN GOVERNMENT REFORESTATION PROGRAM}

The study tour focussed on tree seedling nurseries in the farm forestry sector of the Indonesian forestry. This differs from tree seedling production in the industrial-scale forestry sector, in which seedling nurseries are more capital intensive, are typically owned by medium to large enterprises, produce more than $1 \mathrm{M}$ seedlings per annum, and typically produce seedlings of only one or two tree species. Seedling nurseries supplying farm forestry plantings ${ }^{1}$ are typically not capital-intensive, are owned by community groups, produce considerably less than $1 \mathrm{M}$ seedlings per annum, and typically produce seedlings of multiple species (commonly more than 10 species are grown in a single nursery). Figure 1 presents an example of a community nursery supplying seedlings for farm forestry plantings. Many smallholder nurseries were concentrating on only a few tree species required to support government reforestation program. So the choice of species depends on locations and local demands.

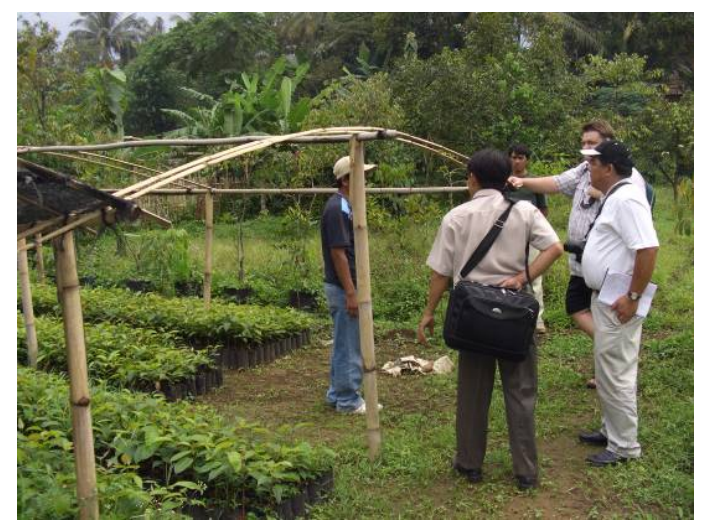

Figure 1. A community nursery in Western Java, Indonesia

A typical value chain for the production of seedlings for farm forestry trees is presented in Figure 2. An important feature of this value chain is the seed procurement process, and how that process involves farmers and supports the procurement of high quality germplasm. Tree seed is collected by farmers under contract to seed assemblers or seed companies (as described by Roshetko et al. 2008). Assemblers link farmer collectors with seed companies and middlemen. Government agencies purchase $75 \%$ of the seed. Cover crop species (not edible), Gmelina arborea, Tectona grandis and Leucaena leucocephala account for the $85 \%$ of the total seed sold. The seed collected comes from a large number of unrelated trees over widely dispersed locations. Simple seed collection guidelines help farmers improve their seed collection

${ }^{1}$ Farm forestry is defined in this article as small-scale plantations established by smallholders typically within or complementary to agroforestry systems or farm woodlots. 
practices and also the genetic quality of seed collected. Seed procurement and diffusion generate substantial income for all seed agents. An estimated 22,500 farmers are involved in seed collection activities annually. Farming families living near seed companies earn additional income by processing seed (Roshetko et al. 2008).

Farmers commonly act as seed collectors contracted by seed aggregators. Aggregators are most commonly privately owned seed companies. The seed companies sell their seed to government agencies.

Government agencies usually facilitate the auction process for seedlings, although they are not directly involved in buying or selling seeds. The winning companies then produce seedlings (sometimes working collaboratively with smallholders) and distribute the seedlings to planting locations. Farm forestry nurseries typically grow a large range of tree species, Gmelina arborea, Tectona grandis and Leucaena leucocephala account for $85 \%$ of the total seed sold). Governments improve their supply of seed using tree seed centres.

Seedling nurseries supplying farm forestry plantings are typically not capital-
intensive, are owned by community groups, produce considerably less than 1
million seedlings per annum, and typically produce seedlings of multiple species
(commonly more than 10 species are grown in a single nursery). Farm forestry
plantings are small-scale forest plantations established by landholders typically
within or complementary to agroforestry systems.

Figure 2. The value chain for seedlings produced in farm forestry tree seedling nurseries in Western Java, Indonesia

Indonesian government agencies play an important role in the supply of seed and the extension of tree seedling production practices for smallholder forestry in Western Java. The Ministry of Forestry is responsible for the development of both the industrial and farm forestry sectors (the organisational arrangement of this structure is shown in Figure 3). The division of the 'Forestry Research and Development Agency', also referred to as FORDA and one of its implementing units, Balai Penelitian Teknologi Perbenihan or BPTP, is responsible for research relating to seedling production, seed quality management and extension activities aimed at fostering appropriate nursery management practices. 


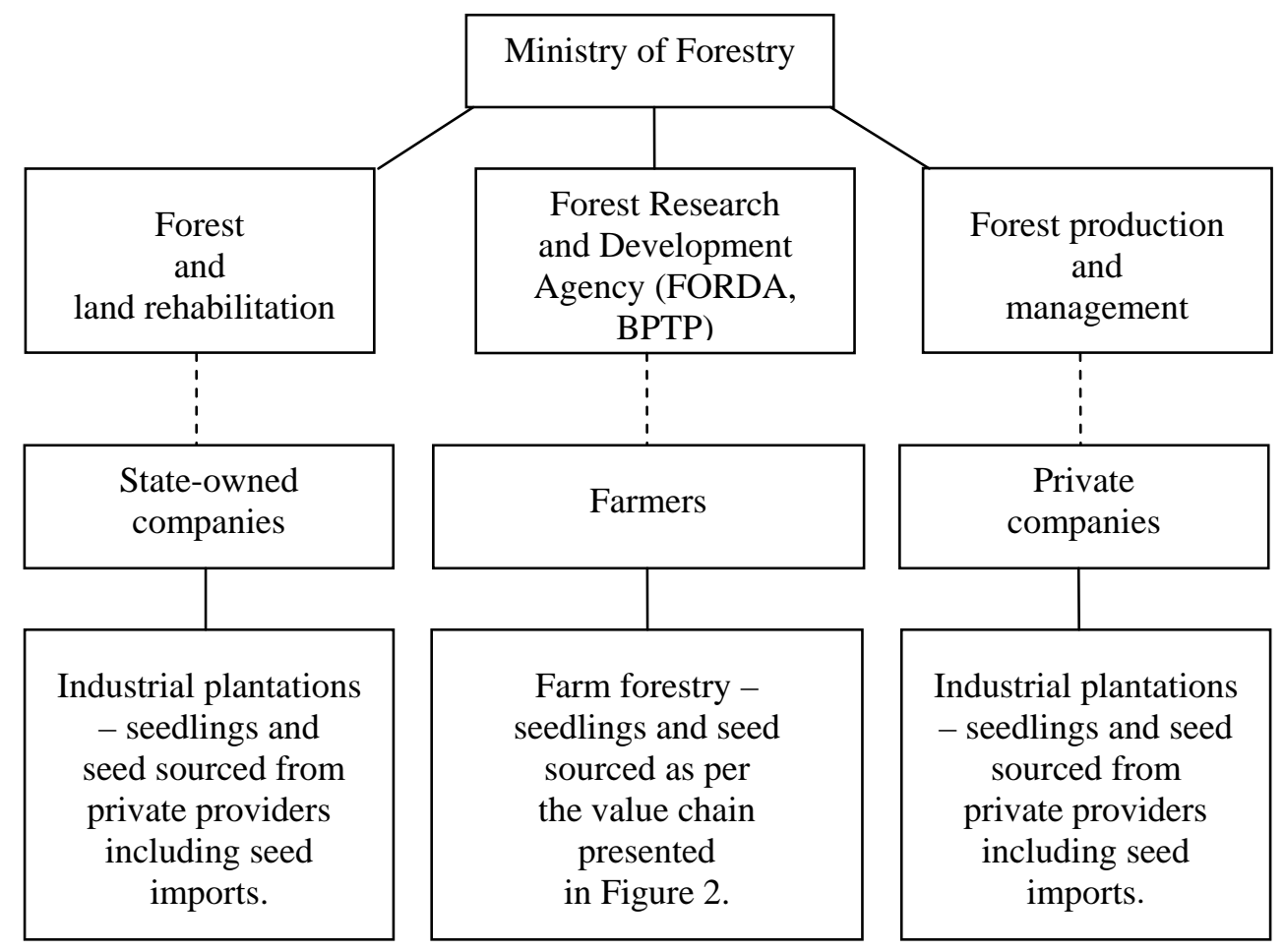

Figure 3. Indonesian Ministry of Forestry organisational structure relating to nursery sector development

Forests and forestry play a major role in Indonesia. Forests cover more than 50\% of the total land area, and are crucial to the country's environment as well as increasingly important to its economy. Forestry has become the second highest export earner after petroleum and natural gas. In 2007, domestic wood product consumption plus export markets amounted to about $60 \mathrm{M} \mathrm{m}^{3}$. It is projected that the total demand will double during the next 25 years. There is a shortfall in wood supplies nationally, and if the current demand trend continues, there will be an annual shortfall of wood supplies by 2020 in the order of $30 \mathrm{M} \mathrm{m}^{3}$ annually.

Some forests in Indonesia are owned by the state and administered by the Ministry of Forestry (MOF) which controls, regulates and manages the forest resources. At the national level, MOF is organized in a line administration structure, while two forestry bodies are recognized at the provincial level, namely regional forestry offices under the MOF, and provincial forestry offices (DINAS) under the provincial governor. The MOF issues forest concession licenses to state-owned and private forestry companies, with a duration of 20 years. Recently, a number of concessions and licenses have been reassessed and revoked by MOF due to severe violations of license conditions.

Reforestation and afforestation add up to only about approximately $50 \%$ of the annual rate of deforestation due to shifting cultivation and land conversion by smallholders, development projects, logging and fire. Due to these losses, Indonesia 
has embarked on a highly ambitious reforestation and afforestation program to produce industrial wood for the country's expanding wood-based industries and to rehabilitate degraded land and natural forest areas that have been logged over.

Government agencies, industrial forestry companies and numerous nongovernment organizations (NGOs) and farmer groups throughout Indonesia are involved with reforestation. All of these groups can make important contributions to rehabilitating the estimated $15.1 \mathrm{M}$ ha of degraded land in Indonesia. The Government of Indonesia (GOI) set an ambitious target of reforesting $3 \mathrm{M}$ ha within the period of 2003 to 2007 (MOF 2003, as cited by Roshetko et al. 2008).

The success of reforestation and tree-planting activities depends on various factors, but in particular tree seed quality and availability. Adequate quantities of seed assure planting targets can be achieved and high seed quality ensures high rates of seed germination and seedling survival. Unfortunately, non-government organizations (NGOs) and farmer groups active in tree planting in Indonesia lack access to tree seed of sufficient quantity and quality (Roshetko et al. 2008) Many reforestation projects of government agencies face similar constraints. In the past, the paucity of information regarding tree seed suppliers aggravated the seed shortage problem. The publication of a directory of Indonesian tree seed suppliers has helped fill this information gap (Roshetko et al. 2008).

The national tree planting activity has its emphasis on fast-growing exotic tree species. This is mainly because tree planters wish to obtain a rapid return on their investment in tree planting as well a general lack of knowledge of the processing and handling of seeds of indigenous tree species. Currently, $75 \%$ of established tree plantations are made up of Acacia mangium, A. auriculiformis, Paraserianthes falcataria, Eucalyptus deglupta, E. europhylla and Tectona grandis.

The seed requirement for these forestation efforts is massive (75-125 t/year), corresponding to the annual demand of about 800 million seedlings. The agents presently involved in tree seed supply include producers, distributors, consumers, controllers and research and development institutions (Roshetko et al. 2008). The tree seed producers in Indonesia are state companies (Inhutani and Perum Perhutani), private companies (mostly concession holders, e.g. Hutan Tanaman Industri), research organizations, and forestry development groups. At the national level, the SubDirectorate of Tree Seed, which is placed under Directorate General of Social Forestry and Land Rehabilitation (DGSFLR), is the government body responsible for all aspects of tree seeds. DGRRL specifies that all state-owned forestry companies are responsible for the production of tree seeds in Indonesia. In other words, Inhutani and Perum Perhutani are tasked to identify and establish the necessary seed sources, and harvest and process the seeds. Sales of seeds and seedlings can be made directly to the forest companies or through intermediaries. Roshetko et al. (2008) reported that 54\% of farmer-collectors sell seeds to companies and $46 \%$ to assemblers. About $80 \%$ of the seed purchased by assemblers is then sold to companies and $20 \%$ to middlemen. Companies sell $24 \%$ of their seed to middlemen or other companies, the remainder are sold to seed customers. Middlemen sell all of their seed to customers. Farmers sell some tree seed to customers in local markets, and assemblers occasionally sell seed directly to consumers, but only limited volumes of seed are sold through these two channels. 
Roshetko et al. (2008) found that $40 \%$ of farmers collect seed exclusively from state plantations, $36 \%$ collect seed exclusively from farmland, and $20 \%$ collect from both sources. Farmers select mother trees according to a limited set of criteria. Tree accessibility and the presence of abundant mature seed are the key criteria, cited by $90 \%$ of farmer collectors. About $66 \%$ of farmers collect seed from tall and mature trees, regardless of tree health and phenotypic quality. Only $8 \%$ of farmers select mother trees taking the health of the tree in consideration, and only $4 \%$ collect seeds from mother trees of species with high timber quality. Individual farmers collect seed from 2 to 5 trees a day. Over the entire seed year, 68\% of farmers collect seed from $40-200$ trees, $12 \%$ from $20-40$ trees, and $20 \%$ from less than 20 trees. Only $4 \%$ of seed collectors have considered the appropriate distance between mother trees during the seed collection process. Ideally, mother trees must be spaced 100 metres apart to promote high a genetic diversity of seeds that will be collected (not a government policy). Regarding seed selection criteria, $80 \%$ of collectors select mature seed, $74 \%$ select healthy and mature fruits, $6 \%$ select seed that is free of pests and diseases, $4 \%$ select large seed, and $4 \%$ select dry seed. About $80 \%$ of farmers pick seed directly from trees, $20 \%$ collect seed from the forest floor and 18\% collect seed from both trees and the forest floor. Pole pruners and hooked bamboo poles are used to collect seed from trees. However, no tree climbing safety equipment is used, nor are traps used to facilitate the gathering of fallen seed.

\section{CLONAL PROPAGATION AND EFFECTIVE PRODUCTION OF HIGH QUALITY SEEDLINGS IN INDONESIA}

One of the highlights of the tour was visiting clonal propagation facilities managed by SEAMEO-BIOTROP, the Korean International Aid Cooperation Agency (KOICA) and the community managed facility of Pundok Pesantren (a Muslim religious group). The SEAMEO BIOTROP is a centre within the SEAMEO (South-East Asian Ministers of Education Organization) which was officially founded in February 1968. The establishment was based on an agreement among the Ministers of Education of South-East Asia, and the member nations, namely Indonesia, Brunei Darussalam, Cambodia, Laos, Malaysia, Myanmar, the Philippines, Singapore, Thailand and Vietnam. There are six associate member countries, namely Australia, New Zealand, Canada, The Netherlands, Germany and France. In 1997, SEAMEO BIOTROP was appointed as the research and development centre for Tropical Biology within the Bogor Agricultural University.

BIOTROP is mandated to conduct research and training, and to service laboratories. It also provides technical advice to clients interested in establishing plantations and tissue culture facilities. It has been propagating genetically superior teak trees (Tectona grandis) for which tissue culture materials were originally taken from Myanmar since 2000. This genetically superior material is designed to satisfy the market requirements in terms of quantity of teak seedlings in Indonesia. BIOTROP has established a hedge garden of teak in Bogor as a source of materials for tissue culture. It has been equipped with laboratory instruments, a greenhouse and nurseries with a production capacity of 50,000 - 100,000 seedlings per month, and sells both plantlets and seedlings. Although seedlings are being propagated mainly for the 
Gerhan project (Indonesia reforestation and rehabilitation project), this facility also caters for the needs of private companies and individuals as well as the local government units. Apart from teak, BIOTROP propagates Cavendish bananas. Figure 4 shows one of BIOTROP's simple clonal propagation chambers.

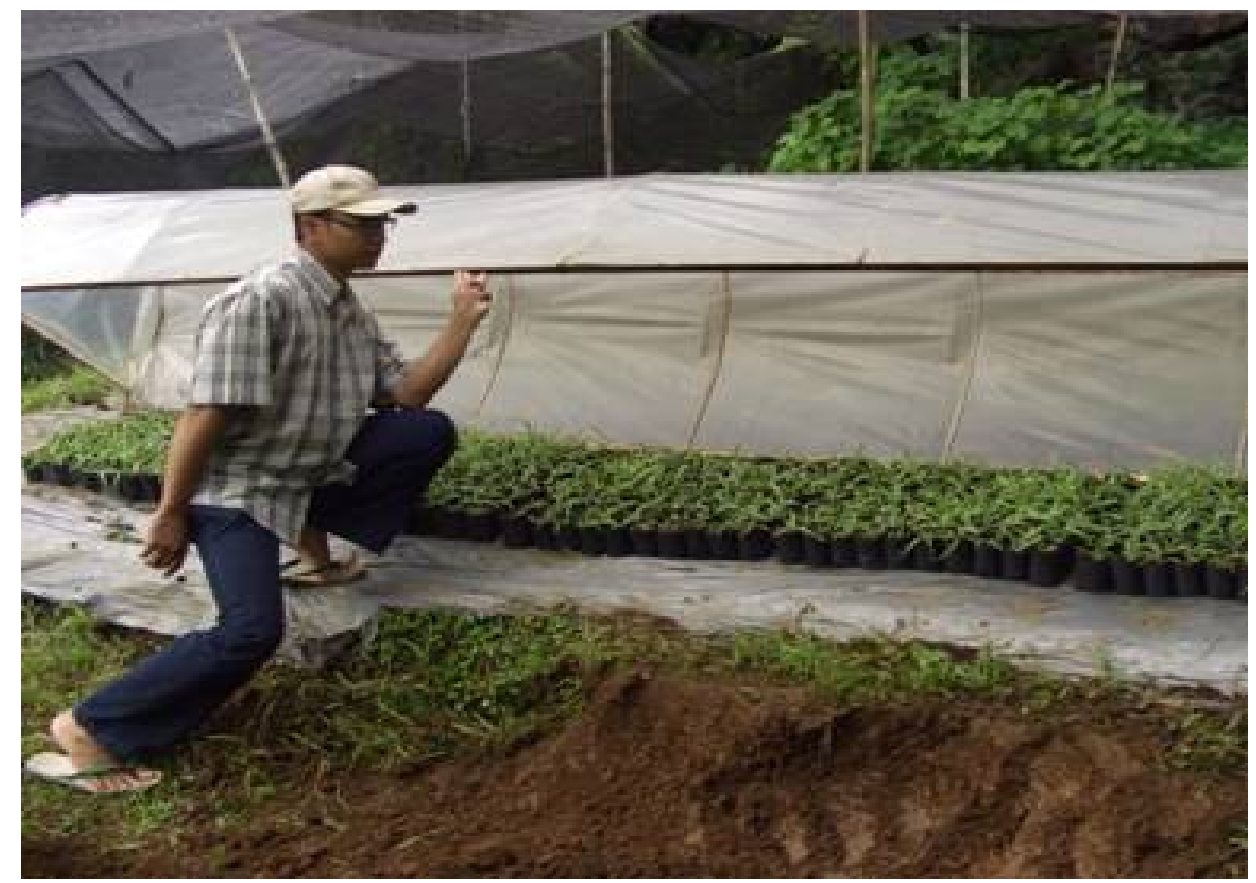

Figure 4. Example of BIOTROP’s simple clonal propagation facilities

The Pundok Pesantren nursery has received financial and technical support from BIOTROP, and BIOTROP has assisted Pondok Pesantren to establish its own tissue culture facility at PT Dafa, Darmaga. The nursery produces 200,000 to 500,000 seedlings a year, mainly of teak and other timber species, as well as bananas and white potatoes. This nursery operates to support the seedling demand of the Gerhan project of the MOF as well as of the Ministry of Agriculture, private companies, individuals and local government units. There is now an increasing demand for tissue cultured plantlets and seedlings in Indonesia due to the increasing understanding by tree farmers and other stakeholders of the benefits of genetically superior planting materials. The MOF places great emphasis on seed and seedling quality in their activities. To ascertain the genetic quality of planting stock, seedling buyers demand that nursery operators provide them with certification from the tree seed centre that seedlings are produced from certified germplasm sources. Further, customers generally ask nursery operators to show their nursery accreditation certificate based on BPTP and BPTH requirements and standards.

A visit was also organized to the facility of the Seed Sources and Nursery Technology Project of the Korean Forest Service (KFS). This US\$2 M project is 
funded by the Korean International Cooperation Agency (KOICA) in partnership with the Indonesian government. The project operates through the collaborative management of a KFS representative and a representative of MOF-Indonesia. The project has state-of-the-art facilities for producing seedlings through tissue culture and mist clonal propagation using cuttings. The project also established cost-effective plastic bubbles as clonal chambers which could be replicated in many parts of Indonesia as well as in other developing countries including the Philippines. Hedge gardens and experimental sites were also established within the nursery compound. The hedge gardens and field trials were planted with genetically superior trees - for species including gmelina, teak, musisi (Maesopsis eminii) and eucalypts - from various tree seed centres across Indonesia.

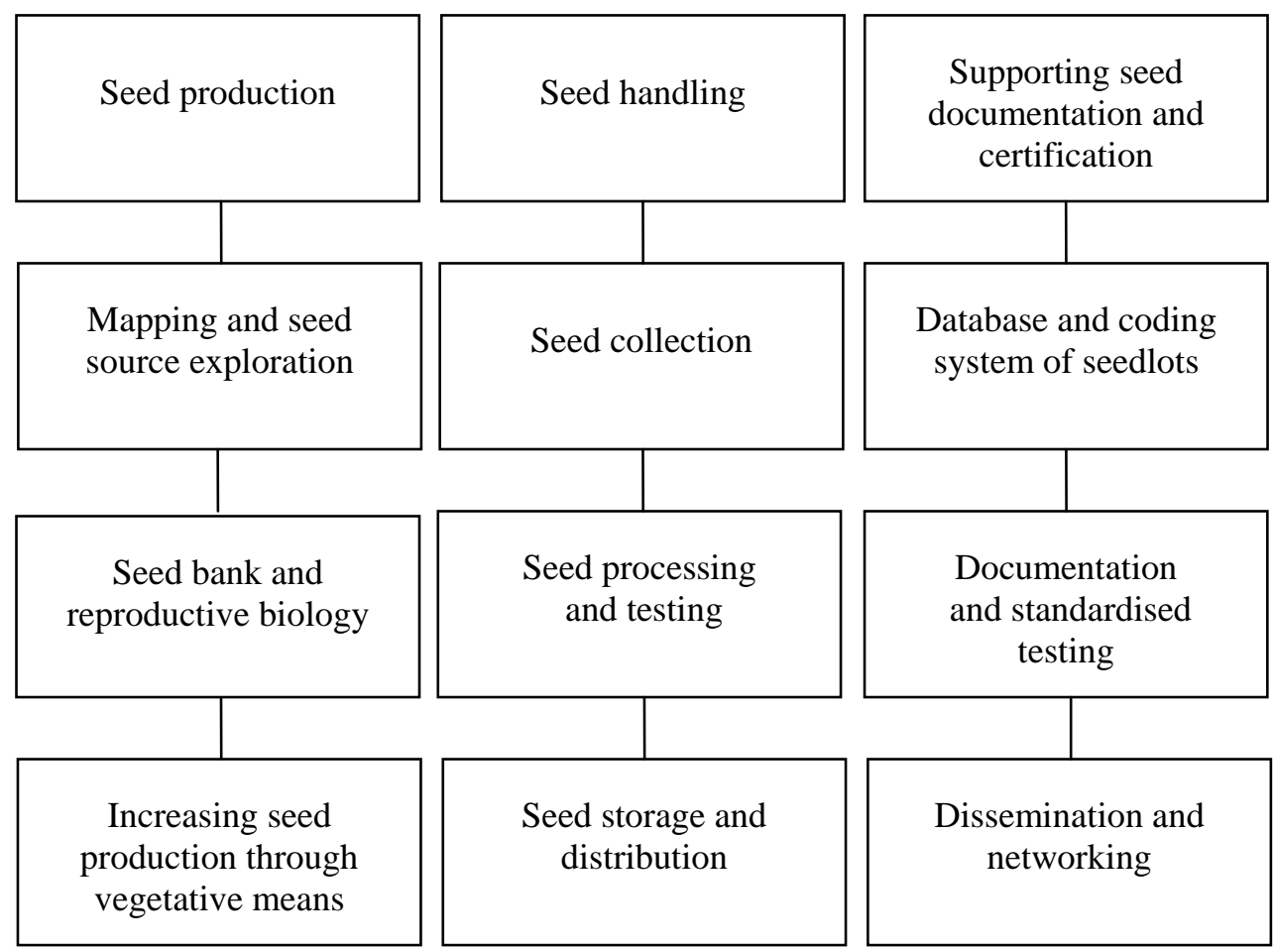

Figure 5. Scope of seedling research and extension activities by the Indonesian Ministry of Forestry's BPTP 


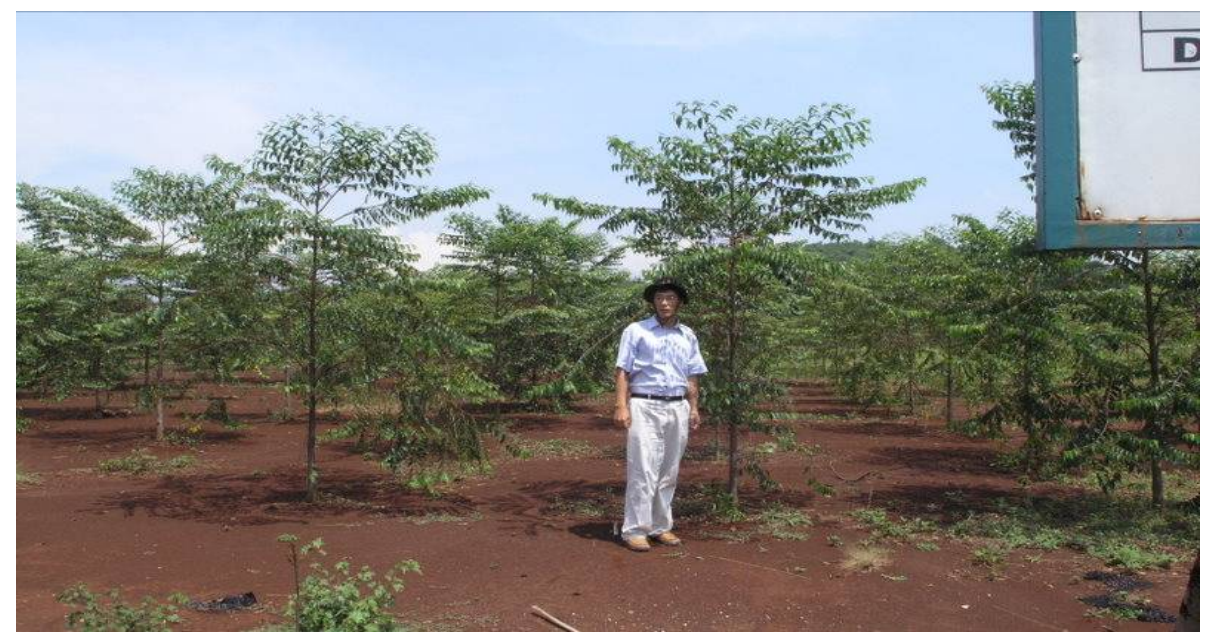

Figure 6. KOICA tree seed centre demonstration plot located near Rumpin in Western Java, Indonesia

The use of genetically superior seedlings is not commonly practiced in smallholder tree farming and large-scale reforestation projects in the Philippines. Unlike in other south-east Asian countries - for example Indonesia, Thailand and Vietnam - where policies regarding the use of high quality seedlings, especially for government-funded reforestation projects, are being implemented, no regulation exists that requires the use of high quality seedlings in the Philippines. It is clear that there is a need for the forestry department in the Philippines to be proactive in promoting genetically superior planting materials both in private and government tree growing activities.

\section{THE ROLE OF FARMER LEADERS IN ADVOCATING THE USE OF HIGH QUALITY PLANTING MATERIALS}

Social mobilization is a cost-effective way of reaching out to more people more quickly, and facilitates collective action among stakeholders. In order to achieve lasting effects and sustained activities, community institution development is an indispensable approach in which people in a community are organized with strong local leadership in order to improve human and social capital towards common goals and objectives. The community nurseries in Cipaku, Cibugel and Bogor are good examples. With the strong leadership of charismatic local leaders, actions and capacities were built and facilitated by MOF and international institutions including ICRAF and CIFOR. In this way, these farmer groups were able to establish, maintain high quality mother trees and nurseries of high quality seedlings as well as to produce and sell high quality seeds. Farmer leaders, who are advocates of high quality seeds and seedlings, are effective in encouraging some of the local people in the community to utilize high quality seedlings. This influence eventually radiates to other people within and outside their communities. 
The charismatic farmer leaders are used by the government as well as local and international research and development agencies to share their skills and talents with other farmers in various places in Indonesia. For example, farmer leaders in Cepaku were brought to Aceh to teach local farmers about technical and institutional innovations on nursery establishment and management. Likewise, farmer leaders in Cibugel were brought to share their technical and institutional expertise with other farmers and farmer associations.

\section{THE BENEFITS OF REGIONAL TREE SEED CENTRES}

One of the most informative visits of this study tour was to Balai Perbenihan Tanaman Hutan (BPTH) at Bandung, West Java. It was a long drive from CIFOR at Bogor, but the smooth drive through the Bogor-Jakarta-Bandung toll road coupled with fantastic views of beautiful Javanese landscapes made the trip enjoyable and rewarding. The BPTH office at Bandung is one of the six regional tree seed centres across Indonesia, and is supported by the Ministry of Forestry (MOF) under the Directorate General of Social Forestry and Land Rehabilitation (DGRRL). DGRRL is the government body responsible for all aspects of tree seed, which is under the technical supervision of Balai Penelitian Teknologi Perbenihan, Bogor (BPTP). The other tree seed centres are located in Madura, Nusa Tenggara, Kalimantan, Sumatra and Papua. The functions of these tree seed centres are to:

- provide advice to interested seed producers and users on all aspects of seed procurement, including seed source identification and establishment, seed collection, processing, testing, storage and distribution;

- approve seed sources owned by various institutions and companies through issuance of certification. Different types of certification are employed for seed sources, seed quality and seedling quality;

- $\quad$ provide seed testing services to seed producers and users;

- establish seed sources including mother trees and clonal hedges and field demonstration plantings;

- prepare, produce and disseminate species-based description of reproduction and flowering systems, fruit and seed development, seed collection, processing, testing and storage, and seed distribution of priority species; and

- plan and implement research and development of tree seed technology.

The establishment of the tree seed centres was made possible through technical and financial support from the Danish International Development Assistance (DANIDA) and the Forest Seed Centre in Denmark (which is also managed by DANIDA). Each centre has about 50 staff members, a line organization structure which consists of the agency director, administrative staff, seed sources section, seeds distribution section, seed information and dissemination section, technical staff (who are involved in research and extension) and a seed testing laboratory.

In order to achieve a broader impact and in consonance with the paradigm shift of the people-oriented forestry program of the DGRRL, a 'Seeds for People Project' was 
conceived which supports community institution development where people in communities are organized into associations or cooperatives. One of the examples is the Makmur group at Cebugel. This was created by BTTH in 2001 with the aim of establishing seed sources managed by a community, and a band of seed collectors travelling around six districts identifying mother trees as well as collecting seed. There are now more than 300 farmer members in this group. The group broadened its operation beyond seed sources and seed quality issues to agroforestry farming, an upland fishery, water supply systems, food processing, animal production, and marketing. This group is producing thousands of seedlings of numerous tree species. However, some seedlings are overgrown in the nursery, because the purchase by the Gerhan project was delayed. It was observed that the Paraserianthes falcataria seedlings were infested with pests.

In order to address this slow turnover of seedlings, the group invited landowners particularly absentees who are living outside Cebugel - to have their land planted to trees, with the groups covering the establishment and maintenance costs, and taking $60 \%$ of the proceeds after all the production costs were deducted. More than 200 ha were planted under this scheme at Cebugel, and invitations were being received from smallholders to extend the scheme outside Cebugel district.

\section{BENEFITS OF SUSTAINED DEMAND FOR TREE SEEDLINGS - IMPLICATIONS FOR THE PHILIPPINES}

One of the greatest business challenges for any nursery operation is how to maintain seedling demand. The major reason for over-mature seedlings in the nursery is that the seedlings are not purchased on time. This problem caused most community nursery operators at Cipaku, Bogor and Cebugel Bandung to lose interest in managing their nurseries. Some nursery operators include the cost of the extended maintenance of over-mature seedlings in the cost of their seedlings particularly for fruit trees.

The problem of overgrown seedlings is not an issue of concern for large-scale nursery operators in Indonesia, especially those supplying planting materials for reforestation program. These nurseries require MOF seedlings purchase orders before they commence seedling production. For example, the Muslim community group Pundok Pesantren at Darmaga was able to mass-produce tissue cultured seedlings of genetically improved teak because of the number of purchase orders from the 'Gerhan' forest rehabilitation project. Private and community-owned nurseries in Indonesia are aiming to capture this high seedling demand from rehabilitation projects. As seeds and seedlings supplied to Gerhan projects need certification from BPTH, obtaining this certification as soon as possible is part of the business strategy considering that early acquisition of the certificate indicates early opportunity to sell the seedlings.

In the Philippines, large demands for seeds and seedlings for the large government reforestation project supported by foreign funds coming from ADB and World Bank are now waning. Nursery operators are now largely relying on sporadic purchases by local government units for small-scale reforestation or watershed rehabilitation projects and from private individuals for farm forestry or agroforestry plantings. Most of these nursery operators are competing for these small demands by reducing the 
price of their seedlings. For example, nurseries in northern Mindanao sell seedlings of mahogany trees at a very low price (about PhP1 each). In the context of such stiff competition, nursery operators producing seedlings at very low cost are compromising seedling quality by following least-cost nursery practices including the collection of seeds from most accessible unselected trees, using very small seedling pots, not sun hardening the seedlings and the use of low quality potting media.

Tree seedling quality can be dramatically improved if there is a sufficient market demand for high quality seed and seedlings. The demand for high quality seed and seedlings will be dramatically improved if more financial resources flow into tree growing. In the Philippines, one of the potential sources of funding for tree growing is the private sector. The Northern Mindanao Tree Growers Federation members, who are mostly wood processors, can put part of their tax dues back into tree growing in order to insure a sustained supply of raw wood materials. One of the reasons for tax evasion in the Philippines is the lack of trust among taxpayers that the government will spend the money wisely for projects of common good and that it will not be pocketed by politicians. This requires a change in the Philippine taxation policy.

Another potential option to increase demand for high quality seedlings is the implementation of a policy on nursery accreditation and requiring recipients of government-funded reforestation projects to purchase high quality planting materials from accredited nurseries. At present, there is no policy that controls the quality of planting materials of forest trees in the Philippines, thus seedling production is largely quantity oriented. Also, there is no regulation for the use of only high quality seedlings in government-initiated reforestation projects.

\section{CONCLUSION}

The main insight gained on the study tour was how the importance of tree seed quality and sound nursery management practices to the success of commercial farm forestry is recognised and valued amongst farm forestry stakeholders in Western Java. The appreciation of germplasm and seedling quality is reflected in 'certified' tree seedlings receiving a preferred status by buyers and a higher price in local markets.

In the Philippines, there are no deliberate efforts to promote tissue culture of forest trees except that of the Claveria Tree Nursery Inc (CTNI) in Claveria, Misamis Oriental. Most of the existing tissue culture facilities are targeted towards the production of horticultural crops including bananas, orchids and potatoes. This is due to the fact that the seedling demand of forest trees does not justify the establishment of such an expensive facility. Private and government reforestation activities generally use low quality planting materials (Gregorio et al. 2008). The recent interest in planting indigenous tree species results in sporadic efforts at clonal propagation of native tree species. Clonal propagation is carried out not mainly to ensure high genetic quality of seedlings but to offset the problem of a germplasm shortage due to infrequent seeding of most native trees. There are a few private nurseries owned by timber companies which operate clonal propagation facilities to cater for their own seedling needs.

The focus on and appreciation of high quality is largely attributable to the extension efforts of FORDA and BPTP staff as well as NGOs including CIFOR. 
FORDA and BPTP place great emphasis on seed and seedling quality in their activities. Seed quality is enhanced by the contribution of the tree seed centres operated by BPTP and by some foreign aid projects, including KOICA which is sponsored by the Korean Government and Swedish International Development Agency (SIDA) and has provided funds to establish eight tree seed centres across Indonesia. Vegetative propagation techniques are also used to good effect in combination with the tree seed centres and certification system, to produce consistently high quality tree seedlings.

A number of important lessons were learnt during this study tour about designing high quality seed and seedling supply systems, which can be implemented in the Philippines to improve seed and seedling quality, including:

1. Nursery operators need to have well-developed entrepreneurial skills ensuring business efficiency.

2. Appropriate technologies to facilitate efficient production of seeds and seedlings (e.g. tissue culture and clonal propagation) should be made available.

3. High credibility and accountability of seed and seedling quality can be achieved by procuring certified seed and seedlings from appropriate sources.

4. Support systems and mechanisms for capacity building, certification and monitoring (e.g. tree seed centres) should be established to ensure compliance with best management practice.

5. A knowledge-sharing system is required to ensure that high seed and seedling quality are appreciated and provided prime attention through community institution development.

6. Private investments are necessary to sustain demands for high quality seed and seedlings, while at the same time keeping nursery businesses flourishing, through tax incentives to wood processors and other businesses that are involved in smallholder tree growing.

7. The Philippine Department of Environment and Natural Resources (DENR), as the government arm, has a proactive role to play in ensuring that tree growers in the Philippines are getting high quality seed and seedlings apart from policing illegal utilization of forest and forest products.

In many ways the Indonesian farm forestry seedling nursery sector is more developed than its equivalent in parts of the Philippines, particularly in Leyte (described by Gregorio et al. 2008 and Mercado and Duque-Piñon 2008). This is arguably the result of more effective longer-standing extension efforts by Indonesian government departments, NGOs and international research organisations including the World Agroforestry Centre (WAC/ICRAF) and Centre for International Forestry Research (CIFOR) that have targeted improvements in germplasm selection and nursery management practices in the nurseries supplying the farm forestry sector.

In conclusion, the study tour was a useful study in identifying some key lessons for the development of the small-scale tree seedling nursery sector in Leyte and Mindanao in the Philippines. Of particular value were observations of how stakeholders in the Indonesian farm forestry sector valued the importance of seed and seedling quality and 
how certification can be used to provide incentives for high quality seedling production through the payment of a premium for certified seedlings. These results complement those reported in Harrison et al. (2008) from similar study tours undertaken in Vietnam and Thailand.

\section{ACKNOWLEDGMENTS}

The field tour reported here was made possible through the support and contribution of various organisations, including ACIAR, ICRAF, FORDA and BPTP Indonesia. We would especially like to thank Jim Roshetko and Pak Dedi Rohadi (from ICRAF) and Pak Agus Pramono and Pak Nurhasybi (from FORDA/BPTP) for their hospitality and guidance.

\section{REFERENCES}

HARRISON, S.R. 2008. A critical overview of forestry seedling production policies and practices in relation to smallholder forestry in developing countries. Small-scale Forestry. 7(3-4): 207-223.

GREGORIO, N.O., HARRISON, S.R. and J.L. HERBOHN. 2008. Enhancing tree seedling supply to smallholders in Leyte Province: an evaluation of the production system of government nursery sector and support to smallholder tree farmers. Small-scale Forestry. 7(3-4): 245-261.

MERCADO, A.R. Jr and C. DUQUE-PIÑON. 2008. Tree seedling production systems in Northern Mindanao, the Philippines. Small-scale Forestry. 7(3-4): 225-243.

ROSHETKO, J.M., MULAWARMAN and A. DIANARTO. 2008. Three seed procurement-diffusion pathways in Wonogiri and Ponorogo, Java. Small-scale Forestry. 7(3-4): 333-352. 